\title{
KEMAMPUAN DAYA BUNUH TERHADAP NYAMUK Anopheles Spp DIBEDAKAN MENURUT LAMA PAPARAN DAN JENIS INSEKTISIDA TAHUN 2015
}

\author{
Ratih Kesuma Wardani ${ }^{1)}$, Aris Santjaka ${ }^{2)}$ \\ Jurusan Kesehatan Lingkungan, Politeknik Kesehatan Kemenkes Semarang, \\ Jl.Raya Baturaden KM 12 Purwokerto, Indonesia
}

\begin{abstract}
Abstrak
Malaria merupakan masalah kesehatan masyarakat yang penting di Indonesia. Upaya pemberantasan yang dapat dilakukan yaitu menekan densitas vektor dengan penyemprotan atau dengan kelambu berinsektisida. Tujuan penelitian ini untuk mengetahui pengaruh lama paparan dan merk insektisida terhadap kematian nyamuk Anopheles Spp. Jenis penelitian yang dipilih eksperimen dengan kualifikasi true experimental design dengan desain penelitian the posttest-only control group design. Uji statistik menggunakan Block Anova kemudian dilanjutkan dengan uji LSD (Least Significant Difference). Hasil penelitian rata-rata kematian nyamuk pada merk insektisida B, $H, V$ dan kontrol secara berturut-turut yaitu 19, 19.5, 18.75 dan 15. Rata-rata kematian nyamuk pada lama paparan 30', 60', 120' dan 3600' secara berturut-turut yaitu 2.75, 19.5, 20 dan 20. Hasil signifikasi menunjukan nilai 0,043 $<\alpha$ $(0,05)$ untuk lama paparan sehingga Ho ditolak artinya ada perbedaan ketahanan nyamuk, berdasarkan lama paparan yang berbeda dan nilai 0,308 $<\alpha(0,05)$ untuk merk insektisida sehingga Ho diterima artinya tidak ada perbedaan merk insektisida dalam membunuh nyamuk Anopheles Spp. Hasil penelitian dapat disimpulkan suhu dan kelembaban nyaman untuk nyamuk. Ada perbedaan lama paparan yaitu antara lama paparan 30', 60', 120' dan 3600' dan tidak ada perbedaan kemampuan merk insektisida dalam membunuh nyamuk Anopheles Spp. Sehingga kemampuan tertinggi daya bunuh nyamuk pada paparan 60 menit.
\end{abstract}

Kata kunci : Anopheles spp, lama paparan, jenis insektisida, kesehatan lingkungan

\begin{abstract}
[The Ability Of The Death Of Anopheles Spp Which Is Differentiated By The Long Treatment And Inseticide Species Brand 2015] Malaria is the most important healthy cause in Indonesia. The effort to eliminate it can be done with the density vector pressure with fogging or insecticide mosquito net. The aims of this research were to find out the ability of the long treatment and insect species of Anopheles Spp mosquito death. This research that have been experimental research with qualification of true experimental design with using the posttest only control group design. Statistic test, the writer used Block Anova, then continued LSD (Least Significant Difference). The result of the research the death mosquito was happened on insecticide brand $B, H, V$, and continuously controlled were 19; 19,5; 18,75; dan 15. The average of the death mosquito happened on long treatment 30', 60, 120', and 3600' continously 2,75; 19,5; 20 and 20. The significant result showed that 0,043 $<\alpha(0,05)$ for along treatment so that Ho was negative. It meant that there was difference of mosquito's defend, basend on of differences of long treatment and took value 0,308 $<\alpha(0,05)$ for insecticide brand, so that Ho was positive, it meant there was not the differences insecticides brand in death an Anopheles mosquito Spp. It can be concluded temperature and humidity was comfortable for mosquito. There was differentation of the long treatment 30', 60', 120' and 3600' and there was mo differentation on insecticide mosquito's ability of the Anopheles mosquito Spp death. There fore, the high ability of mosquito's death happened on 60 minutes of the treatment.
\end{abstract}

Keywords : Anopheles spp, long exposure, insecticides, environmental health

\section{PENDAhUluan}

Malaria merupakan masalah kesehatan masyarakat yang penting di Indonesia. Di daerah transmigrasi dan daerah lain yang didatangi penduduk baru dari daerah non-endemik, sering terjadi letusan atau wabah yang menimbulkan banyak kematian. Lebih dari setengah penduduk Indonesia masih hidup di daerah dimana terjadi penularan malaria, sehingga berisiko tertular malaria.
Angka prevalensi penyakit malaria di Indonesia pada tahun 2012 mencapai 417.819 kasus positif. Dengan jumlah $70 \%$ kasus malaria terdapat di wilayah Indonesia Timur, terutama diantaranya Papua, Papua Barat, Maluku, Maluku Utara, Sulawesi dan Nusa Tenggara. Wilayah endemik malaria di Indonesia Timur tersebar di 84 kabupaten/kota dengan jumlah penduduk berisiko 16 juta orang. (Dirjen P2B2, 2013)

1) Email : ratihmawardani@yahoo.co.id

2) Email : arissantjaka@gmail.com 
Upaya pemberantasan yang dapat dilakukan adalah menekan densitas vektor, sehingga risiko penularan Plasmodium fase gamet dapat ditekan seminimal mungkin. Salah satu upaya pemberantasan nyamuk malaria adalah pemakaian kelambu yang terbuat dari bahan yang sudah dicampur dengan insektisida yaitu Long Lasting insecticide Nets (LLi'Ns). Keuntungan pemakaian kelambu yang dicelup insektisida antara lain adalah cara pencelupan kelambu yang sederhana dan mudah karena tidak memerlukan peralatan dan keahlian khusus, sangat efektif dalam memberi perlindungan kepada masyarakat dari gigitan nyamuk dan biayanya cukup murah.

Pemakaian LLi'Ns dilakukan oleh pemerintah, tetapi kelambu tersebut sangat mahal untuk ukuran masyarakat desa yang mayoritas petani dan buruh tani dengan lahan yang sangan terbatas dan tinggal di daerah terisolir karena kasus malaria sering terjadi di daerah remote area. Harga satu kelambu untuk ukuran satu tempat tidur dua ratus ribu rupiah dan kelambu tidak dijual bebas. Sehingga kelambu hanya diberikan di daerah khusus terutama daerah KLB.

Masyarakat sebenarnya mampu untuk membeli kelambu dari kain untuk tempat tidurnya, namun kelambu tersebut belum berinsektisida. Keterbatasan anggaran pemerintah dalam pengadaan kelambu LLi'Ns karena mahal dan kemampuan terbatas masyarakat untuk membeli kelambu, maka peneliti memberi solusi yaitu pengadaan kelambu berinsektisida, kelambu tersebut merupakan kelambu yang ada akan direndam dalam insektisida yang ada di pasaran seperti B, V dan H. B mengandung 3 bahan aktif yaitu sipermetrin 0,4 g/lt, imiprotin 0,32 g/lt, dan transflutrin 0,2 g/lt. V mengandung 3 bahan aktif yaitu praletrin $0,572 \mathrm{~g} / \mathrm{lt}$, d-aletrin 3,245 g/lt, dan siflutrin 0,286 gr/lt sedangkan $\mathrm{H}$ mengandung transfultrin 1,436 gr/lt. Kandungan bahan aktif yang berbeda tersebut memiliki kemampuan membunuh yang berbeda. Waktu paparan insektisida akan memberikan kemampuan mereduksi nyamuk Anopheles Spp yang berbeda. Secara teoritis semakin lama waktu paparan bertambah, kemampuan daya bunuh terhadap nyamuk juga semakin tinggi. Dengan lama paparan yang ideal belum diketahui, untuk itu perpaduan antara merk insektisida dan lama paparan akan membentuk gambaran yang lebih jelas kemampuan daya bunuhnya. Peneliti memaparkan nyamuk selama 30 menit (WHO).

Pengendalian nyamuk dengan kelambu berinsektisida sangat efektif karena dapat melindungi masyarakat, terutama bayi, anak balita dan ibu hamil yang sangat rentan terhadap penyakit malaria dari gigitan nyamuk penular malaria dan nyamuk-nyamuk penular penyakit lainnya. Penggunaan kelambu paling efektif jika penggunanya benar-benar berada di bawah kelambu dari tengah malam sampai subuh saat nyamuk
Anopheles Spp biasanya menghisap darah. Berdasarkan kenyataan bahwa kelambu dapat berperan sebagai sawar antara nyamuk dengan manusia, maka dipikirkan penggunaan kelambu yang dikombinasikan dengan insektisida sehingga dapat membunuh dan/atau menghalau nyamuk sekaligus.

Penggunaan kelambu insektisida memberikan perlindungan individu yang signifikan, tetapi efek langsung dan tidak langsung kelambu insektisida dan kelambu tidak berinsektida terhadap penularan malaria masih sedikit dipahami (Gonosiu, dkk., 2008). Efektifitas kelambu berinsektisida tergantung dari kontak langsung dengan nyamuk.

Tujuan penelitian ini adalah mengetahui pengaruh lama paparan dan merk insektisida terhadap kematian nyamuk Anopheles Spp.

\section{BAHAN \& METODE}

Penelitian termasuk jenis penelitian eksperimen dengan kualifikasi true experimental design karena memenuhi syarat adanya perlakuan, control, replikasi, dan randomisasi. Desain penelitian yang dipilih the posttest-only control group design yaitu salah satu disain penelitian eksperimen yang membandingkan hasil eksperimen antara kelompok perlakuan dan kelompok kontrol.

Populasi dalam penelitan adalah nyamuk Anopheles Spp. Sampel yang digunakan dalam penelitian adalah nyamuk Anopheles Spp yang dipilih secara random sejumlah 20 ekor nyamuk Anopheles Spp pada setiap kelambu.

Uji statistik yang digunakan adalah uji Block Analisis of Variance (Block Anova) dan dilanjutkan dengan uji LSD (Least Significant Difference)

\section{III.HASIL DAN PEMBAHASAN}

Hasil rata-rata kematian nyamuk Anopheles Spp berdasarkan merk insektisida pada merk insektisida B dengan lama perendaman 15 menit rata-rata kematian nyamuk adalah 19. Pada merk insektisida $\mathrm{H}$ dengan lama perendaman 15 menit rata-rata kematian nyamuk adalah 19,5. Pada merk insektisida $\mathrm{V}$ dengan lama perendaman 15 menit rata-rata kematian nyamuk adalah 18,75. Dan pada kontrol rata-rata kematian nyamuk adalah 15 . Merk insektisida $\mathrm{B}, \mathrm{H}$, dan $\mathrm{V}$ memiliki kandungan bahan aktif yang berbeda-beda, sehingga memilki kemampuan membunuh yang berbeda-beda juga.

Hasil pengamatan dan perhitungan rata-rata kematian nyamuk Anopheles Spp berdasarkan lama paparan dapat dilihat pada tabel 4.2. Berdasarkan tabel tersebut menunjukkan bahwa jumlah kematian nyamuk Anopheles Spp pada lama paparan 30 menit rata-rata kematian nyamuk adalah 12,75 . Pada lama paparan 60 menit rata-rata kematian nyamuk adalah 19,5. Pada lama paparan 120 menit rata-rata kematian nyamuk adalah 20. Dan pada lama paparan 24 jam rata-rata kematian nyamuk 20. 
Suhu ruangan diukur menggunakan thermometer ruangan, pengukuran dilakukan pada saat pengamatan. Hasil pengukuran suhu ruangan tercatat berkisar antara $26,1^{\circ} \mathrm{C}-26,7^{\circ} \mathrm{C}$, suhu tersebut relative cocok untuk perkembangan nyamuk. Suhu lingkungan yang optimum untuk perkembangan nyamuk adalah $25^{\circ} \mathrm{C}-27^{\circ} \mathrm{C}$.

Nyamuk termasuk binatang berdarah dingin sehingga metabolisme dan siklus kehidupannya tergantung pada suhu lingkungan, sehingga pengaturan suhu tubuh sangat tergantung pada lingkungannya. Pada suhu kurang dari $16^{\circ} \mathrm{C}$ dan lebih tinggi dari $32^{\circ} \mathrm{C}$ nyamuk akan mengalami gangguan pertumbuhannya, suhu optimum pertumbuhan nyamuk, $25^{\circ} \mathrm{C}-27^{\circ} \mathrm{C}$. Perubahan suhu sangat berpengaruh pada nyamuk, secara umujm perubahan antara $5^{\circ} \mathrm{C}-6^{\circ} \mathrm{C}$ nyamuk tidak tahan hidup dan akan mengalami kesulitan berdapatasi.

Kelembaban ruangan diukur menggunakan alat hygrometer, pengukuran dilakukan pada saat pengamatan. Hasil pengukuran kelembaban ruangan tercatat berkisar antara $80 \%-84 \%$, kelembaban tersebut relative cocok untuk perkembangan nyamuk.

Variabel independen yang di uji adalah merk insektisida dan lama paparan, dari tabel signifikansi kedua variabel tersebut mendapat nilai signifikan $=0,308$ yang berarti nilai $\mathrm{p}>$ nilai $\alpha(0,05)$ untuk merk insektisida nilai signifikan $=0,043$ yang berarti nilai $\mathrm{p}<$ nilai $\alpha(0,05)$ untuk lama paparan.

Analisa yang dilakukan menggunakan uji Block Anova, kemudian dilanjutkan menggunakan uji LSD (Least Signifficant Difference) untuk mengetahui perbedaan lama paparan 30 menit, 60 menit, 120 menit dan 24 jam terhadap kematian nyamuk Anopheles Spp. Berdasarkan uji statistik yang telah dilakukan yaitu apabila nilai signifikansi $>\alpha(0,05)$, maka hipotesa peneliti ditolak dan sebaliknya apabila nilai signifikansi $<\alpha(0,05)$ maka hipotesa peneliti diterima.

Hasil uji Block Anova menunjukkan nilai $\mathrm{p}=0,043$, berarti $<\alpha(0,05)$ sehingga Ho ditolak atau dengan kata lain ada perbedaan ketahanan nyamuk Anopheles Spp, berdasarkan lama paparan yang berbeda.

Lama paparan kelambu yang digunakan dalam penelitian ini adalah lama paparan 30', 60', 120’ dan 24 jam perbedaan lama paparan tersebut pada waktu kontak nyamuk dengan jenis insektisida, semakin lama kontak nyamuk dengan merk insektisida daya bunuh terhadap nyamuk akan semakin tinggi.

Hasil uji Block Anova untuk berbagai merk insektisida nilai $\mathrm{p}=0,308>\alpha(0,05)$, berarti Ho diterima dengan kata lain tidak ada perbedaan kemampuan merk insektisida dalam membunuh nyamuk Anopheles Spp.

Tidak ada perbedaan kematian nyamuk Anopheles Spp pada berbagai merk insektisida, kemampuan daya bunuh merk insektisida sama sehingga tidak ada beda dalam membunuh nyamuk.
Hasil analisis dilanjutkan menggunakan uji LSD (Least Signifficant Difference) untuk mengetahui perbedaan lama paparan 30 menit, 60 menit, 120 menit, dan 24 jam.

Berdasarkan uji LSD dapat disimpulkan bahwa ada perbedaan lama paparan lama paparan 30' dengan lama paparan 60', 120', dan 3600'.

Hasil analisis dapat disimpulkan lama paparan yang paling efektif pada lama paparan 60 menit karena pada 60 menit nyamuk kontak dengan berbagai jenis insektisida. Cara kerja bahan aktif untuk mematikan nyamuk yaitu bahan aktif yang telah terserap oleh kelambu setelah direndam dengan berbagai jenis insektisida, maka kelambu mempunyai daya racun, bahan aktif insektisida akan masuk kedalam tubuh nyamuk yang hinggap pada kelambu berinsektisida dan mengganggu sistem syaraf seperti pyrethroid. Pyrethroid termasuk dalam golongan transflutrin. Pyrethroid merupakan racun axonik yaitu beracun terhadap serabut syaraf. Terikat pada protein serabut syaraf yang dikenal sebagai voltage-gated sodium channel. Pada keadaan normal, protein ini membuka untuk memberikan rangsangan pada syaraf dan menutup untuk menghentikan sinyal syaraf. Pyrethroid terikat pada voltage-gated sodium channel dan mencegah penutupan secara normal yang menghasilkan rangsangan syaraf berkelanjutan. Hal ini menyebabkan tremor dan gerakan inkoordinasi pada nyamuk yang keracunan dan dapat menyebabkan kematian pada nyamuk.

\section{IV.KESIMPULAN}

Kondisi lingkungan nyaman untuk kelangsungan hidup nyamuk dengan suhu rata-rata $26,3^{\circ} \mathrm{C}$ dan kelembaban rata-rata $82 \%$. Jumlah kematian nyamuk Anopheles Spp tertinggi pada merk insektisida $\mathrm{H}$ dengan lama perendaman 15 menit rata-rata kematian nyamuk adalah 19,5 dan jumlah kematian nyamuk Anopheles Spp terendah pada merk insektisida $\mathrm{V}$ dengan lama perendaman 15 menit rata-rata kematian nyamuk adalah 18,75. Jumlah kematian nyamuk Anopheles Spp tertinggi pada lama paparan 120 menit dan 24 jam rata-rata kematian nyamuk adalah 20 dan jumlah kematian nyamuk Anopheles Spp terendah pada lama paparan 30 menit rata-rata kematian nyamuk adalah 12,75. Merk insektisida yang paling efektif yaitu jenis insektisida $\mathrm{H}$ dan lama paparan yang paling efektif yaitu pada lama paparan 60 menit. Merk insektisida mempunyai kemampuan daya bunuh yang sama secara statistika.

\section{DAFTAR PUSTAKA}

Cahyono, Tri. 2014. Pedoman Penulisan Proposal Penelitian dan Karya Tulis Ilmiah/Skripsi (Edisi Revisi Ketiga). Jurusan Kesehatan Lingkungan Purwokerto Poltekkes Kemenkes Semarang. 
Chasan S, Kusnadi, 2006. Pengendalian Vektor dan Binatang Penganggu. Makassar: Instalasi Penerbitan Jurusan Kesehatan Lingkungan Poltekkes Makassar

Departemen Kesehatan Republik Indonesia.2007 Survey Entomologi Malaria. Direktorat Jendral Pemberantasan Penyakit dan Penyehatan Lingkungan Pemukiman. Jakarta.

Departemen Kesehatan Republik Indonesia. $2007^{g}$.Ekologi Dan Aspek Perilaku Vektor. Direktorat Jendral Pemberantasan Penyakit Menular Dan Penyehatan Lingkungan Pemukiman : Jakarta

Rampengan, T.H. 2010. Malaria pada Anak dalam P.N. Harijanto. Malaria dari Molekuler ke Klinis. EGC. Jakarta.

Santjaka, A. 2011. Statistik untuk Penelitian Kesehatan (Deskriptif, Inferensial, Parametrik dan Non Parametrik). Nuha Medika. Yogyakarta.
Santjaka, A. 2013. Malaria Pendekatan Model Kausalitas. Nuha Medika. Yogyakarta.

Santjaka, A. 2014. Pembuatan Kelambu Insektisida Guna Menekan Densitas Vektor Malaria dalam Rangka Percepatan Pencapaian MDG's. Jurusan Kesehatan Lingkungan Purwokerto Poltekkes Semarang.

Santjaka, A. 2014. Aplikasi SPSS untuk Analisis Data Penelitian Kesehatan, Nuha Medika. Yogyakarta.

Sari, L.K., Safni dan Zalfa. 2012. Degadasi Senyawa Sipermetrin dalam Insektisida Ripcord 5 ECsecara Fotolisis dengan Penambahan $\mathrm{Tio}_{2}$ /Zeolit. Jurnal Kimia Unand. Volume 1 Nomor 1 hal : 76-81

Soedarto, 2003. Zoonosis Kedokteran. Cetakan I. Universitas Airlangga. Surabaya.

Soedarto, 2008. Parasitologi Klinik. Airlangga University Press. Surabaya.

Soedarto, 2011. Malaria, Jakarta: CV Sagung Seto. 